\title{
KONFLIK SUNNI-SYIAH PASCA ARAB SPRING: MENELUSURI MOTIF POLITIK DIBALIK PERANG BERKEPANJANGAN DI SURIAH
}

\author{
Irvan Tasnur \\ Mahasiswa Program Pascasarjana \\ Universitas Negeri Yogyakarta \\ Irvantasnur.2018@student.uny.ac.id \\ Fitra Widya Wati \\ Dosen Jurusan Pendidikan Sejarah \\ Universitas Negeri Makassar \\ Widyafitah@gmail.com
}

\begin{abstract}
Abstrak
Perang Suriah adalah salah satu konflik berkepanjangan yang telah berlangsung selama delapan tahun lamanya. Sulitnya menemukan titik damai menjadi penyebab kandasnya usaha pengentasan konflik di negara tersebut. Penelitian ini bertujuan untuk menelusuri motif dibalik terjadinya peperangan di negara Suriah menggunakan pendekatan Historis. Hasil telaah dan analisis didapatkan bahwa Suriah sebagai negara sekular, memisahkan antara kehidupan bernegara dan beragama, selain itu Suriah juga merupakan negara etnoreligius yang damai sebelum perang merusak sendi-sendi kehidupan di sana. Bashar al Assad sebagai presiden Suriah memeluk ajaran Syiah sekte Awali yang merupakan sekte minoritas di Suriah, pengangkatannya dan juga ayahnya didukung oleh sebagian besar tokoh militer yang bermazhab Sunni. Pemaparan di atas jelas menunjukkan bahwa perbedaan mazhab antara Sunni dan Syiah di Suriah bukan menjadi penyebab utama terjadinya perang yang panjang. Lebih dalam lagi, hasil analisis menunjukkan terdapat berbagai kelompok yang bertikai di negara tersebut yaitu kelompok Pemerintah Suriah, Pasukan Demokratik Suriah (Rojava, SDF, QFD), Negara Islam Irak dan Syam (ISIS), Jabhat al-Nusra, dan Oposisi Suriah. Sulitnya penyelesaian konflik yang terjadi diSuriah bukan hanya disebabkan oleh banyaknya kelompok interen yang bertikai dan memiliki tujuan serta kepentingan masing-masing, namun hal ini semakin diperparah juga oleh adanya keterlibatan negara-negara lain seperti Rusia, Arab Saudi, Iran, Israel, Turki, Amerikan, Ingris dan Prancis yang membawa berbagai macam motif dan kepentingan, hal inilah yang menyebabkan sulitnya tercipta konsensus yang mengarah kepada perdamaian di Suriah.
\end{abstract}

Kata Kunci: Konflik, Kelompok, Sunni, Syiah, Kepentingan.

\begin{abstract}
The Syrian War is one of a long-standing conflict that has lasted for eight years. The difficulty of finding a peaceful spot is the cause of the conflict eradication efforts in the country. This study aims to explore the motives behind the war in Syria using the Historical approach. The results of the study and analysis found that Syria as a secular state,
\end{abstract}


separating between state and religious life, besides that Syria is also a peaceful ethnoreligious state before the war-damaged the joints of life there. Bashar al Assad as Syrian president embraced the Shia teachings of the Awali sect which is a minority sect in Syria, his appointment as well as his father were supported by most of the military figures who were Sunni schools. The above explanation clearly shows that the differences in schools between Sunnis and Shiites in Syria are not the main cause of a long war. Deeper, the results of the analysis show that there are various conflicting groups in the country, namely the Syrian Government, the Syrian Democratic Forces (Rojava, SDF, QFD), the Islamic State of Iraq and Sham (ISIS), Jabhat al-Nusra, and the Syrian Opposition. Difficult resolution of conflicts that occur is not only caused by the many internal warring groups that have their own goals and interests, but this is also made worse by the involvement of other countries such as Russia, Saudi Arabia, Iran, Israel, Turkey, America, Britain and France that carry a variety of motives and interests, this is what makes it difficult to create a consensus that leads to peace in Syria.

Keywords: Conflict, group, Sunni, Shia, Interest.

\section{PENDAHULUAN}

Suriah atau yang lebih dikenal dengan nama resminya sebagai Republik Arab Suriah merupakan salah satu negara yang berlokasi di kawasan Asia Barat. Suriah atau Siria berbatasan dengan Lebanon dan Laut Mediterania di sebelah barat, disisi utara berbatasan dengan Turki serta berbatasan dengan Yordania Selatan dan Israel di bagian Timur. Penduduk Suriah berjumlah kurang lebih 18,27 juta jiwa dan terdiri atas sekitar 74 persen Muslim, 14 persen sekte-sekte muslim serta 10 persen menganut agama kristen (Burge, 2010: 31). Suriah adalah negara yang cukup luas, bila dilihat sekilas di peta dunia, dapat di perkirakan bahwa luasnya kurang lebih duapuluh kali lebih luas dari Negara Lebanon. Namun, dari total luas tersebut hanya 28 persen wilayahnya dapat digunakan sebagai ladang pertanian.

Suriah sebagai negara modern, baru berdiri pada tahun 1946 pasca perang dunia kedua. Pasca kemerdekaannya tersebut, Suriah dipimpin oleh sekelompok elitee militer sehingga dalam perjalanan pemerintahannya terbilang kurang mulus, diakibatkan kerap kali terjadi kudeta yang dilakukan di antara pembesar militer akibat adanya perebutan takhta kekuasaan(Kinsal, 2014: 108). Puncak intrik politik yang dilakukan oleh militer terjadi pada tahun 1973 yang ditandai dengan pengangkatan Hafezh al-Assad sebagai presiden baru. Periode ini kemudian menjadi titik balik bagi stabilisasi pemerintahan Suriah, namun kuatnya posisi 
Hafez tersebut tetap mendapatkan oposisi yang melahirkan beberapa pemberontakan sebagai suatu implikasi panjang dari perubahan-perubahan tersebut.

Permasalahan konflik yang terjadi di Suriah umumnya digambarkan sebagai konflik bermotif agama, melibatkan antara dua kelompok besar aliran kesilaman yaitu Syiah-sunni. Namun, terlebih dahulu penulis akan mencoba menganalisis secara mendalam mengenai latar belakang pimpinan dan masyarakat yang melakukan usaha revolusi sehingga terjadi konflik berkepanjangan. Selain itu, pada umumnya kedaulatan suatu negara juga dapat diintervensi secara tidak langsung maupun terstruktur bila negara lain mempunyai kepentingan besar terhadap negara tersebut baik dari sisi ekonomi maupun politik. Maka dari itu, latar belakang pimpinan Negara Suriah, faktor faktor yang menjadi penyebab terjadinya pemberontakan, serta proses penyelesaian konflik yang terjadi akan dikaji secara mendalam menggunakan pendekatan historis menggunakan metode sejarah yang terdiri dari heuristik, kritik, interpretasi dan historiografi.

\section{PEMBAHASAN}

\section{Hafezh Al Assad, Partai Ba'ats, Syiah Awali dan Sunni}

Assad lahir pada tanggal 6 Oktober 1930 dari keluarga yang menganut sekte alawiyah yang merupakan salah satu aliran sekte Syiah yang ada di Suriah. Dia merupakan seorang anggota angkatan udara yang juga merupakan anggota pendiri Partai Ba'ats di Suriah. Partai ini juga disebut sebagai Al-Hizb al-Ba'ath al'Arabi al-Isyitiraki atau Partai Kebangkitan Arab Sosialis yang menganut paham nasionalisme dan sosialisme (Winanda, 2015: 1). Bila melihat kembali sejarah partai Ba'ats, partai ini lahir dan didirakan oleh sorang kristen yang bernama Michel Aflaq dan Salahuddin Bitar yang merupakan penganut islam sunni. Partai ini menganut paham sekularisme atau pemisahan kehidupan beragama dan negara atau pemerintahan.

Assad adalah orang yang tidak condong dan memihak kepada salah satu agama yang ada di Suriah. Dia juga adalah orang yang menentang terhadap ideologi komunisme dan adanya gerakan Pan-Suriah yang menghendaki 
penyatuan seluruh wilayah yang lebih luas dari Suriah modern yakni Levente dalam bahasa Prancis atau Asy-Syam dalam bahasa Arab. Hal tersebut dijelaskan oleh Petrick Seale dalam bukunya Asad: The Struggle for The Middle East bahwa:

"The Ba'ths struggles of those years against Pan-Syrians, Communists, and the whole of the right with the muslim brothers in the van, gave him his political education and informed his attitudes to movements with forty years later were still present on the Syrian scene" (Seale, 1990: 37).

Pengalaman inilah yang kemudian membuatnya menjadi seorang yang dapat mempertahankan kekuasaan sebagai seorang presiden selama kurang lebih 29 tahun lamanya. Tidak adanya keinginan untuk menyatukan negara-negara bekas Suriah lama kedalam negara Suriah menyebabkan dia bukan hanya mendapatkan dukungan dari dalam negaranya namun juga mendapat dukungan dan legitimasi dari negara-neara tetangganya yang merupakan bekas wilayah Asy-Syam. Selain itu, kecenderungannya yang tidak memihak salah satu agamapun menjadi nilai tersendiri bagi kuatnya fondasi yang dibangun oleh Assad.

Sekte alawi atau alawiya merupakan aliran salah satu sekte Syiah yang dianut oleh Assad, Namun, seperti yang telah diungkapkan sebelumnya hal tersebut tidak mempengaruhi kecondongan politik Assad dikarenakan sekte tersebut merupakan aliran yang hampir menerapkan beberapa ritual atau kepercayaan yang terdapat di setiap agama dan aliran kepercayaan di Suriah. Sekte alawi yang dianut oleh Assad tidak mengikuti fiqih Ja'fari yang dianut oleh paham Syiah pada umumnya, namun mengikuti fiqih Hanafi dan Maliki walaupun dalam penerapannya sekte ini tidak mewajibkan anggota kelompoknya untuk mengamalkan syariat apapun, bahkan Syiah sendiri menolak untuk mengakui sekte alawi sebagai salah satu aliran Syiah (Ahlul Bait Indoneisa, 2012:98). Salah satu bukti tidak berjalannya syariat yang terdapat dalam sekte alawi yakni pemasukan tari dan musik dalam ritual keagamaan serta adanya izin meminum alkohol (Lebor, 2010: 295) yang di mana hal tersebut bertentangan dengan syariat keislaman. 
Bila memperhatikan latar belakang politik serta agama atau sekte yang dianut oleh Assad, tidak ada alasan yang menguatkan untuk melakukan justifikasi bahwa terdapat dua arah arus perpolitikan yaitu Sunni-Syiah di dalam pemerintahan Suriah. Terlebih penerapan sistem sekularisme dalam pemerintahan di mana terdapat jurang lebar yang memisahkan antara kehidupan beragama dan kehidupan pemerintahan. Namun, meskipun Assad tidak memiliki kecondongan politik pada salah satu agama, hal tersebut tidak menghilangkan kecurigaan yang dilakukan oleh sebagian besar kelompok Sunni. Matthew Gordon dalam bukunya Hafez Al-Assad: World Leader Past \& Present menjelaskan bahwa Many Sunnis Accused Assad and the other member of comite of discrimination and nepotism (Gordon,1989, 57). Tetapi kecurigaan tersebut tidak berlangsung lama, sikap nepotisme tersebut tidak terbukti ditandai dengan pengangkatannya sebagai presiden yang didukung oleh sebagian besar militer yang bermazhab Sunni.

\section{Bashar al- Assad: Menjadi Presiden}

Bashar lahir di Damaskus pada tanggal 11 September 1965, dia mempunyai latar belakang ilmu kedokteran yang didapatnya di Universitas Damaskus pada tahun 1988. Sama halnya dengan ayahnya Hafezh, dia memegang kepercayaan sekte Syiah alawi. Partai Ba'ats melalui Abd Al-Halim Khaddam yang mempunyai pengaruh yang sangat besar di Suriah khususnya terhadap kebijakan dalam pemerintahan serta pemilihan presiden, menunjuk atau mendeklarasikan Bashar al Assad sebagai Presiden setelah ayahnya meninggal pada bulan june tahun 2000. Untuk memuluskan Bashar menjadi presiden, Khaddam membuat suatu aturan baru yang memungkinkan pengangkatan Bashar sebagai presiden. Eyal Ziser dalam bukunya Commanding Syria: Bashar Al-Asad and the First Years in Power menjelaskan bahwa setelah meninggalnya Hafez Al Asa'd Khaddam ditunjuk sebagai pengganti sementara, dengan kapasitas yang dimilikinya dia kemudian mengeluarkan dekret presiden yang memungkinkan Bashar Al-Assad menjadi seorang presiden (Ziser, 2007: vi).

Aturan atau derkret presiden yang dimaksud dalam memuluskan pengangkatan Bashar sebagai presiden adalah mengusahakan perubahan batas 
ambang usia seorang presiden Suriah. Hal tersebut dijelaskan oleh Volker Perthes dalam bukunya Syria under Bashar al-Asad: Modernisation and the Limits of Change bahwa setelah kematian Hafez Al-Assad diumumkan, beberapa jam setelahnya Khaddam dan seluruh parlemen yang kebanyakan terdiri dari unsur militer dan partai Ba'ats sebagai mayoritas melakukan penggodokan terhadap batas ambang usia seorang presiden Suriah. Pembicaraan yang dilakukan tidak membutuhkan waktu lama dan menghasilkan perubahan batas ambang usia presiden yang tadinya maksimal berumur 40 tahun menjadi 34 tahun.

Setelah syarat sebagai seorang presiden telah terpenuhi maka diadakanlah referendum pemilihan presiden yang memenangkan Bashar al Assad sebagai presiden dengan total perolehan suara 97,3\%. Peristiwa inilah yang kemudian menandai perubahan besar perpolitikan di negara Suriah. Tidak lama setelah terangkat menjadi presiden, Bashar bergerak dengan cepat mengalang dan memperkuat jaring-jaring kekuasaan dengan merangkul pihak militer mengingat posisinya yang kurang kuat karena tidak memiliki backgroun ttersebut, walaupun tidak bisa dipungkiri bahwa wibawah ayahnya masih membuatnya tetap disegani. Selain itu, dia juga merangkul seluruh golongan elite untuk memperkuat posisinya di tampuk kekuasaan Suriah.

\section{Konflik Sunni - Syiah: Suatu Faktor ke Arah Pergolakan Suriah}

Kemunculan orang-orang yang menggolongkan dirinya sebagai golongan Sunni maupun Syiah adalah sejarah panjang dari peradaban islam. Awal adanya ketidak sepahaman tersebut lahir setelah wafatnya nabi Muhammad SAW pada tahun 632 Masehi. Ketidaksepahaman ini muncul terkait pemilihan orang yang pantas untuk meneruskan jabatan Khalifah. Kubu umat muslim kemudian terbagi menjadi dua golongan utama yakni mereka yang mendukung pengangkatan Abu Bakar As Siddiq (sunni) dan mereka yang mendukung pengangkatan Ali bin Abu Talib (Syi'ah). Terlepas dari apa yang dipaparkan ddi atas, perbedaan-perbedaan tadi kemudian semakin meruncing ketika adanya ketidak sepahaman mengenai hal-hal yang bersifat keagamaan yakni yang terkait dengan ritual keagamaan, hadis, fiqih dan lain sebagainya. 
Sebenarnya bila ditinjau secara mendalam, Suriah adalah negara yang etnoreligius dan merupakan negara sekular yang memisahkan praktik keagamaan dan pemerintahan. Walaupun dipimpin oleh Bashar al-Assad yang menganut paham Syiah sekte Alawi, kehidupan masyarakat Suriah adalah harmoni antara seluruh agama yang terdapat di negara tersebut. Konflik yang terjadi di Suriah adalah sebuah peristiwa yang sangat kompleks yang harus dijabarkan secara mendalam dan komprehensif. Menurut Prof. Glen E Robinson konflik yang terjadi di Suriah adalah konflik yang disebabkan akibat adanya dominasi kaum minoritas dalam negara yang miskin serta gagal tanpa adanya toleransi (Robinson, 2012: 334)

Melihat kembali sisi historis, Alawi merupakan sekte yang telah lama berada di kawasan Suriah yang pada saat itu berada di bawah kekuasaan Turki Usmani. Pada masa ini awali hidup didaerah terpencil pegunungan guna menjauhkan diri dari diskriminasi. Dalam sejarahnya, Awali pernah mengalami beberapa kali peristiwa pembantaian yakni pada tahun 1317 Masehi dengan jumlah korban 20.000 jiwa dan pembantaian yang terjadi 1516 dengan jumlah korban 10.000 jiwa (Pipes,1989: 435). Peristiwa ini merupakan sejarah kelam yang pernah terjadi antara dua golongan besar yakni Sunni dan Syiah khususnya mereka yang menganut sekte Alawi.

Konflik saudara yang terjadi di Suriah pada awalnya merupakan konflik yang berlangsung diakibatkan adanya tekanan atau dominasi pemerintah dan golongan elite penguasa. Tekanan tersebut kemudian di respons dengan aksi-aksi demonstrasi yang dilakukan oleh masyarakat guna menuntut kebebasan masyarakat untuk ambil bagian dalam bidang ekonomi dan politik. Awal konflik ini tidak pernah membawa atribut keagamaan apapun. Pada bulan maret 2011 terjadi aksi demonstrasi oleh orang-orang yang menyatakan sebagai kelompok pro demokrasi di Deraa sebagai buntut dari rentetan peristiwa yang dikenal sebagai Arab Spring. Arab Spring sendiri menurut Carlo Panara dan Garry Wilson dalam bukunya The Arab Spring: New Patterns for Democracy and International Law didefenisikan sebagai suatu serangkaian protes di dunia Arab yang berlangsung di Tunisia, Libiya, Mesir, Yaman dan beberapa daerah lain (Panara, 2013: ix). 
Protes-protes tersebut kemudian ditanggapi dengan cara yang konfrontatif kepada pihak demonstran yang mengakibatkan terjadinya kerusuhan di Suriah. Kelompok-kelompok lain pun bermunculan yang kemudian direspons dengan cara yang lebih agresif. Konflik yang terjadi antara oposisi dan pemerintah ini kemudian meluas ketika adanya isu agama yang di bawah oleh kedua belah pihak yang menimbulkan rasa sinisme terhadap sekte alawi Syiah yang memimpin negara Suriah. Menurut Dr. Taufik Ramadhan Al- Buthi, bahwa Syiah telah eksis lama di Suriah dan merupakan minoritas, Sunni pun hidup berdampingan dengan bebagai sekte yang ada di Suriah (Majelis Ulama Indonesia, 2017:27). Bertasarkan keterangan tersebut dapat disimpulkan bahwa harmonisasi selama berabad-abad lamanya antara Sunni dan Syiah rusak akibat adanya provokator yang membawa atribut keagamaan dalam perebutan kekuasaan.

Adapun pemberitaan-pemberitaan mengenai konflik Suriah yang melibatkan antara Sunni dan Syiah bila diamati hanya merupakan faraming yang dilakukan oleh media dan sebenarnya kurang tepat. Hal tersebut dikarenakan kelompok yang berperang di Suriah bukan hanya terjadi antara kelompok yang menyatakan dirinya Sebagai Sunni dan Syiah, akan tetapi juga telah melibatkan organisasi-organisasi yang beragam, serata akibt adanya cara pandang yang berbeda mengenai sistem pemerintahan yang seharusnya dijalankan. Terdapat beberapa kelompok yang melakukan perebutan wilayah yang berlangsung hingga sekarang yaitu kelompok dari Pemerintah Suriah, Pasukan Demokratik Suriah (Rojava, SDF, QFD), Negara Islam Irak dan Syam (ISIS), Jabhat al-Nusra, dan Oposisi Suriah. Hal tersebutlah yang membuat penyelesaian konflik di Suriah sangat sulit untuk mencapai titik terang, karena melibatkan banyak kelompok dan permasalahan yang sangat kompleks, terlebih dengan adanya keterlibatan oleh negara-negara lain.

Melihat harmonisasi agama dan sekte yang ada di Suriah, sangat sulit rasanya untuk menyimpulkan bahwa penyebab terjadinya konflik saudara adalah adanya perbedaan cara pandang keagamaan dari masing-masing kelompok mengingat perang yang terjadi melibatkan banyak organisasi dan kepentingan-kepentingan didalamnya. Namun, terlepas dari penyebab utama 
terjadinya konflik yang ada di Suriah jumlah korban yang tercatat pada peristiwa ini yakni 470.000 jiwa namun dalam catatan PBB menyebutkan korban dari peristiwa ini yakni sebanyak 400.000 jiwa. Selain korban jiwa ratusan penduduk Suriah banyak memutuskan keluar dari negaranya untuk mencari suaka ke luar negeri. Perang tersebut menyebabkan pula kondisi ekonomi Suriah yang terpuruk dan penurunan jumlah penduduk, tercatat selama lebih dalam kurun waktu tujuh tahun yaitu dari tahun 2010-2017 jumlah penurunan jumlah penduduk sebanyak kurang lebih tiga juta jiwa.

\section{Sulitnya Melangkah ke Arah Perdamaian}

Sulitnya tercipta perdamaian di Suriah seperti yang dijelaskan sebelumnya disebabkan oleh banyak faktor, salah satu faktor utama penyebab sulitnya mencapai kata sepakat diakibatkan oleh permasalahan yang dihadapi bukan hanya melibatkan satu pihak tetapi melibatkan banyak kelompok dan kepentingan yang turut ambil bagian dalam peperangan. Banyaknya pihak yang terlibat akibat adanya asas kepentingan terhadap negara Suriah menyebabkan semakin meruncingnya jurang pemisah antara Suriah dan perdamaian. Kondisi ini kemudian diperparah dengan banyaknya negara-negara lain ikut ambil bagian memanfaatkan kekacauan yang terjadi di negara tersebut.

Moritz Peper dari Universitas Salford mengungkapkan bahwa salah satu negara yang memiliki andil besar terhadap terjadinya konflik berkepanjangan di Suriah adalah negara Rusia, ikut campuranya disebabkan oleh adanya motif ekonomi, politik serta pertahanan. Bagi Rusia, Suriah adalah benteng pertahanan utama yang membatasi dan mencegah islamis radikal masuk serta melakukan aksinya di negara rusia. Maka dari itu tidak mengherankan apabila Rusia kemudian memutuskan ikut campur dalam urusan dalam negeri Suriah dengan dalih bahwa negara tersebut adalah kawan lama dari Suriah mengingat di negara tersebut partai sosialis (Paratai Ba'ats) besar dan berkembang.

Selain negara Rusia yang mempunyai kepentingan terhadap negara Suriah, posisi yang strategis membuat negara Iran harus mendukung pemerintahan Suriah dalam mengatasi pemberontakan, hal ini dikarenakan Suriah merupakan jembatan 
penghubung antara Iran dan Libanon. Apabila Suriah kemudian jatuh ketangan kelompok ekstrimis Isis maupun Sunni maka jembatan tersebut akan tidak dapat lagi dilalui oleh Iran, hal inilah yang nantinya diprediksi akan menyebabkan kekacauan akibat sulitnya Iran memasok persenjataan ke Libanon. Selain itu, pemimpin Suriah yaitu Bashar al Assad yang memiliki landasan keislaman Syiah menjadi penguat Iran untuk terlibat lebih jauh lagi pada urusan dalam negeri Suriah.

Tidak sampai disitu, kepentingan Ideologis dan politik juga mengharuskan Turki ikut andil dalam peperangan yang terjadi di Suriah untuk mencegah penguasaan golongan Kurdi terhadap Suriah bagian Utara yang posisinya sangat dekat dengan Turki. Kekhawatiran tersebut bersumber dari adanya prediksi terjadinya penguatan Partai Pekerja Kurdistan (PKP), apabila wilayah tersebut dikuasai oleh pemberontak Kurdi. Walaupun dalam prakteknya kaum kurdi dan turki memiliki arah mazhab yang sama yakni sunni namun hal tersebut tidak mencegah terjadinya peperangan antara kedua kelompok tersebut. Maka dari itu konflik yang selama ini diisukan hanya melibatkan golongan Sunni-dan Syiah adalah hanya salah satu faktor dari sekian banyak penyebab terjadinya perang berkepanjangan di Suriah.

Negara besarpun seperti Arab Saudi kemudian juga turut ikut ambil bagian dalam peperangan, terlibatnya negara ini merupakan upaya pencegahan penyebaran Syiah di kawasan Middle East oleh Iran. Seperti yang telah dibahas sebelumnya bahwa sanya, Sunni dan Syiah mulai terpecah setelah meninggalnya nabi Muhammad yaitu pada abad ke 7 Masehi. Jurang pemisah yang begitu lebar antara Sunni dan Syiah disebabkan perbedaan tradisi-tradisi keagamaan yang ada dalam Mazhab besar tersebut. Israel yang merupakan negara yahudi tidak tinggal diam dan memutuskan untuk ikut ambil bagian dalam peperangan yang terjadi di Suriah diakibatkan adanya kepentingan untuk mencegah pengaruh Hizbullah menguat di Suriah yang mengancam kedaulatan Israel.

Banyaknya kepentingan baik itu ekonomi, politik, hingga pertahanan dari negara-negara lain menyebabkan Amerika juga sebagai negara Super Power ikut ambil bagian dengan alasan memiliki kepentingan untuk membasmi ISIS, begitu 
halnya juga dengan Jerman dan Prancis yang memiliki alasan yang sama. Walaupun bila dicermati ikut ambil bagiannya negara-negara lain seperti Amerika dan lain sebagainya lebih pas bila dikatakan memiliki motif ekonomi yang sangat besar di negara Suriah, mengingat negara tersebut merupakan salah satu negara penghasil minyak terbesar di dunia. Deskripsi ddi atas memperlihatkan sangat besarnya keterlibatan dan unsur kepentingan negara lain dalam perang Suriah yang kemudian mengakibatkan sulitnya Suriah mencapai konsensus dalam perdamaian.

\section{KESIMPULAN}

Konflik Suriah adalah konflik berkepanjangan yang melibatkan banyak organisasi, kelompok, kepentingan dan negara. Bila dilihat dari motif terjadinya konflik tidak ada hal yang mengindikasikan bahwa awal terjadinya konflik tersebut bermotif agama atau renggangnya hubungan antara Sunni dan Syiah. Walaupun Hafez dan Bashar memeluk kepercayaan Syiah sebagai Mazhab keislamannya, atau sekte Syiah Awali namun hal tersebut tidak banyak mempengaruhi pola politik dari kedua tokoh tersebut mengingat sekte tersebut adalah golongan minoritas yang ada di Suriah. Selain itu, kedua tokoh tersebut dalam pengangkatanya sebagai seorang presiden didukung oleh golongan militer yang sebagian besar bermazhab Sunni. Suriah juga merupakan negara etnoreligius yang tenteram sebelum terjadinya perang besar yang menewaskan puluhan ribu jiwa.

Pemaparan di atas jelas mengindikasikan bahwa, isu perang yang dilatar belakangi konflik antara golongan Sunni dan Syiah, hanya merupakan salah satu faktor penyebab terjadinya peperangan besar di negara tersebut. Banyak faktor-faktor lain yang menyebabkan terjadinya perang berkepanjangan di negara Suriah yaitu antaralain disebabkan oleh kepentingan ekonomi, politik, ideologi, dan juga pertahanan. Banyaknya negara lain yang terlibat dalam urusan dalam negeri Suriah menjadi penyebab utama sulitnya mengurai konflik dan terciptanya konsensus berskala nasional maupun internasional. 


\section{DAFTAR PUSTAKA}

Ahlul Bait Indonesia. 2012.Buku Putih. Mazhab Syiah: Menurut Para Ulamanya yang Muktabar. Jakarta: Dewan Pengurus Pusat.

Burge, Garry. M. 2010. Palestina Milik Siapa?. Semarang: BPK Gunung Mulia.

Gordon, Matthew. 1989. Hafez Al-Assad: World Leader Past \& Present. New York: Chelsea House Publisher.

Kinsal Masni Handanyani. 2014. Penyelesaian Konflik Internal Suriah Menurut Hukum Internasional. Manado: Universitas Sam Ratulangi. Jurnal Lex Et Societatis Vol. II/ No. 3/April/2014.

Lebor, Adam. 2010. Pergulatan Muslim di Barat: Antara Identitas dan Integrasi. Jakarta: Mizan.

Majelis Ulama Indonesia. 2017. Majalah Mimbar Ulama: Islam Wasathiyah Ruh Gerak MUI.Jakarta: Komisi Infokom MUI.

Panara, Carlo, Gary Wilson. The Arab Spring: New Patterns for Democracy and International Law. Leiden: Martinus Nijhoff Publishers.

Phipes, Deniel. 1989. The Awali Capture of Power in Syria. Jurnal Middle Eastern Studies, Vol. 25 No. 4 (October 1989).

Robinson, Robert E. 2012. Syria's Long Civil War. Philadelphia : Jurnal Current History.

Seale, Petrick. 1990. Asad: The Struggle for The Middle East. Amerika: University of California Press.

Winanda, Vergie. 2015. Sejarah Perkembangan Partai Baath di Irak pada Masa Kepemimpinan Saddam Hussein Tahun 1979-2003. Yogyakarta: Universitas Negeri Yogyakarta. Jurnal Risalah Vol. 1/No. 3/ 2016.

Ziser, Eyal. 2007. Commanding Syria: Bashar Al-Asad and the First Years in Power. Losndon: I. B. Tauris. 